\title{
Distributional and natural history notes for Bromeliohyla dendroscarta (Anura: Hylidae) in Veracruz, Mexico
}

\author{
Víctor Vásquez-Cruz, ${ }^{1}$ Luis Canseco-Márquez, ${ }^{2}$ and Arleth Reynoso-Martínez ${ }^{1}$ \\ ${ }^{1}$ Herpetario Palancoatl, Avenida 19 número 5525, Colonia Nueva Esperanza, C.P. 94540, Córdoba, Veracruz, Mexico. \\ E-mail: victorbiolvc@gmail.com; arleth.rm21@gmail.com. \\ 2 Departamento de Biología Evolutiva, Museo de Zoología, Facultad de Ciencias, UNAM. AP 70-399 México, D.F. 04510, \\ Mexico. E-mail: lcanseco@gmail.com.
}

\begin{abstract}
Distributional and natural history notes for Bromeliohyla dendroscarta (Anura: Hylidae) in Veracruz, Mexico. Two new locality records are reported for the critically endangered hylid frog, Bromeliohyla dendroscarta, in Veracruz, Mexico. The frogs were found in semideciduous tropical forest, an ecotone of semideciduous tropical forest and mountain cloud forest, and an agricultural mosaic; none of these habitats has been documented previously for this species. Information is provided on larval feeding habits, duration of larval development under natural conditions and external morphology of tadpoles.
\end{abstract}

Keywords: Altas Montañas region, morphology, reproduction, semideciduous tropical forest, tadpoles, Tillandsia sp.

\begin{abstract}
Resumen
Notas distributivas y de historia natural de Bromeliohyla dendroscarta (Anura: Hylidae) en Veracruz, México. Se reportan dos nuevos registros de localidades para la rana hílida en peligro crítico, Bromeliohyla dendroscarta en Veracruz, México. Las ranas se encontraron en bosque tropical semicaducifolio, un ecotono de bosque tropical semicaducifolio y bosque mesófilo de montaña, y un mosaico agrícola, ninguno de estos hábitats ha sido documentado previamente para esta especie. Se proporciona información sobre hábitos de alimentación larvales; También se informa la duración del desarrollo larvario en condiciones naturales y la morfología externa de los renacuajos.
\end{abstract}

Palabras clave: bosque tropical semicaducifolio, morfología, Región de las Altas Montañas, renacuajos, reproducción, Tillandsia sp.

Received 11 December 2018

Accepted 25 March 2019

Distributed June 2019 


\begin{abstract}
Resumo
Notas de distribuição e história natural de Bromeliohyla dendroscarta (Anura: Hylidae) em Veracruz, México. Dois novos registros de localidade são relatados para o hilídeo Criticamente Ameaçado Bromeliohyla dendroscarta, em Veracruz, México. Os animais foram encontrados em uma floresta tropical semidecídua, um ecótono de floresta tropical semidecídua, uma floresta montana e um mosaico agrícola. Nenhum desses habitats foi documentado anteriormente para essa espécie. São fornecidas informações sobre hábitos alimentares larvais, duração do desenvolvimento larval em condições naturais e morfologia externa dos girinos.
\end{abstract}

Palavras-chave: Floresta tropical semidecídua, girinos, morfologia, região de Las Altas Montañas, reprodução, Tillandsia sp.

\section{Introduction}

Mexico ranks fifth in the world for amphibian species diversity, and more than $60 \%$ of its species are endemic (Parra-Olea et al. 2014). Unfortunately, Mexico also ranks second in the world for the number of threatened amphibian species (Stuart et al. 2006). Several different factors have a negative effect on amphibian populations. Destruction, fragmentation, and modification of natural habitats often is considered the main cause amphibian declines (Frías-Álvarez et al. 2010), but disease (e.g., chytridiomycosis), pollution, invasive species, overexploitation, increase in ultraviolet radiation, and global climate change also are important, and often act synergistically (Collins and Storfer 2003, Lips et al. 2008, Rovito et al. 2009, Aranda-Coello et al. 2018). Many Mexican species of amphibians that are listed as threatened on the IUCN Red List have remained undocumented by scientists for decades, because either the populations have been extirpated or the species have cryptic habits that hinder sampling (Kays and Allison 2001, Canseco-Márquez et al. 2018). Consequently, there often are substantial gaps in our knowledge of basic natural history, such as microhabitat use and breeding phenology, of these amphibians (Delia et al. 2013).

Hylidae is one of the most diverse anuran families in Mexico, with 99 described species (Frost 2018), of which about 68\% are endemic
(Parra-Olea et al. 2014) and about 59\% are threatened (Frías-Alvarez et al. 2010). In a recent surge in fieldwork, several species of Mexican hylids that were "lost" to science for several decades have been rediscovered (e.g., Delia et al. 2013, Caviedes-Solis et al. 2015, BarriosAmorós et al. 2016, Grünwald et al. 2016, García-Bañuelos et al. 2017, Canseco-Márquez et al. 2018). One such species is the Mexican endemic Bromeliohyla dendroscarta (Taylor, 1940) (García-Bañuelos et al. 2017, CansecoMárquez et al. 2018), which is associated with bromeliads in cloud forest and pine-oak forest. The confirmed distribution of this species is limited to the states of Puebla, Oaxaca, and Veracruz (Canseco-Márquez et al. 2018). Several additional records of $B$. dendroscarta in Hidalgo (Hernández-Salinas and Ramírez-Bautista 2012) and in the Sierra de Los Tuxtlas in Veracruz are questionable. Molecular, morphological, and acoustical studies of available specimens are needed (fide Duellman 2001, Lamoreux et al. 2015, Lemos-Espinal and Smith 2016, CansecoMárquez et al. 2018) to verify the identity of these frogs and the locality records. Bromeliohyla dendroscarta is listed in NOM-059SEMARNAT-2010 as Subject to Special Protection (SEMARNAT 2010) and as Critically Endangered on the IUCN Red List (SantosBarrera and Canseco-Márquez 2004). Many aspects of the biology of this species and the status of its populations remain unknown. 
Here, we provide novel distribution records for $B$. dendroscarta, along with information on larval feeding habits, the duration of larval development under natural conditions, and the external morphology of the larvae. We also comment on notable ecological aspects as observations on the diet of the larvae of $B$. dendroscarta and briefly discuss their implications for conservation.

\section{Materials and Methods}

Our study area is a region known as "Las Altas Montañas" in west-central Veracruz. The specific locality is Colonia Agrícola Rincón de las Flores (1843'12.02" N, 96 50'54.59" W; $1150 \mathrm{~m}$ a.s.l.; Figure 1), in the municipality of Tezonapa. The predominant vegetation is semideciduous tropical forest (Figure 2 A, B); however, there also is an ecotone of semideciduos tropical forest and montane cloud forest (Figure 2C), along with patches of shade-grown coffee (Coffea arabica L.), banana (Musa sp.), and camedor palm (Chamaedorea elegans Mart.) (Figure 2D).

The field work was opportunistic. We sampled our study area in 2015 (19-20 March), 2017 (02-03 October), and 2018 (12-13 May), using visual encounter surveys focused on microhabitats often inhabited by amphibians, including bromeliads. We performed surveys from 09:00-13:00 $\mathrm{h}$ and from 21:00-01:00 h. Four people participated in each survey, for a total of 192 person-hours of survey time. Tadpoles and egg clutches that we discovered during these surveys were georeferenced (WGS 84 ) and subsequently monitored on 03, 06, 09, 10, and 13 October 2017 and 06 February 2018.

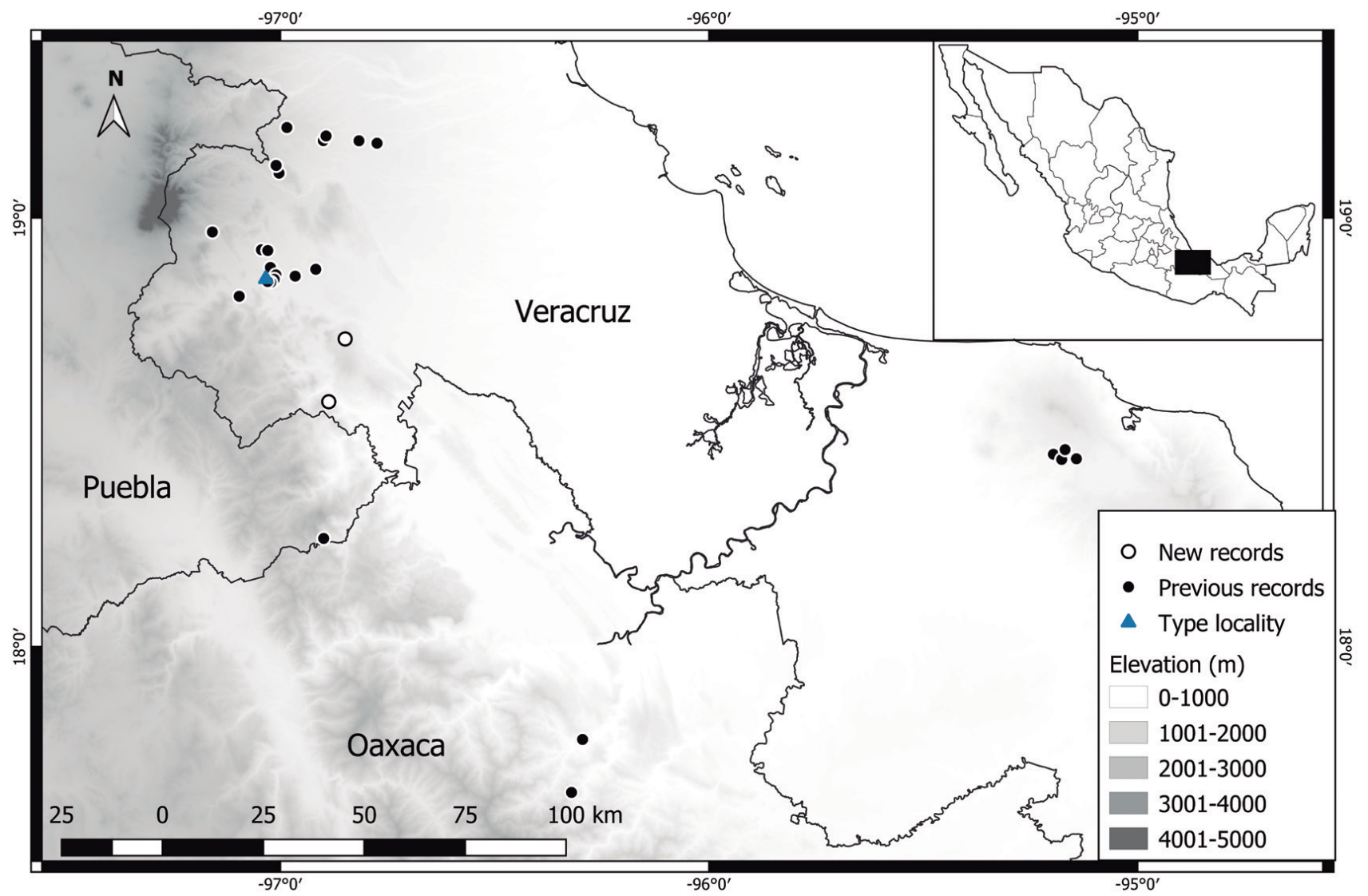

Figure 1. Geographic distribution of Bromeliohyla dendroscarta, showing the new localities. 

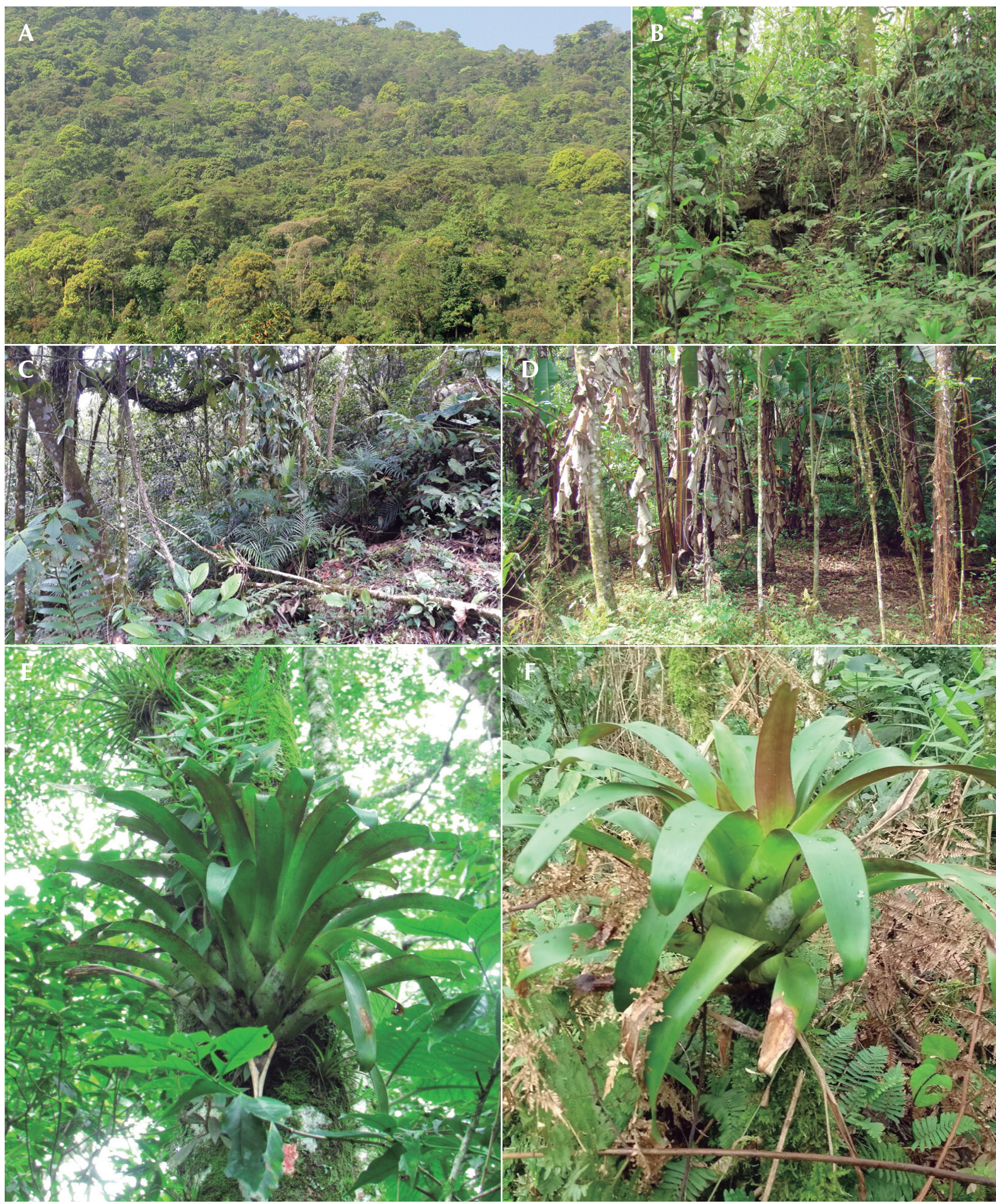

Figure 2. Habitat occupied by Bromeliohyla dendroscarta in the Colonia Agrícola Rincón de las Flores, Tezonapa, Veracruz: semideciduous tropical forest $(\mathbf{A}, \mathbf{B})$; semideciduous tropical forest and mountane cloud forest $(\mathbf{C})$; mixed agriculture of shade-grown coffee, banana and camedor palm (D); and Tillandsia sp. microhabitat $(\mathbf{E}$, F). Photos by Víctor Vásquez-Cruz (A, B), Raul Andrés Díaz-Ramos (C, F), Arleth Reynoso-Martínez (D), and Alfonso Kelly-Hernández (E). 
We identified all living frogs using Duellman (1964, 2001) with supplemental comparison against Canseco-Márquez et al. (2018) and followed the taxonomy of Frost (2018). Gosner (1960) and Gómez et al. (2016) were used to describe embryonic and larval morphology. We used a FastestDrops MX 60× portable microscope and a Samsung WB100 digital camera to observe and record images of eggs and tadpoles.

\section{Results}

On 20 February 2015 at ca. 11:00 h, in a forest mosaic of planted coffee, native trees with abundant bromeliads and other epiphytes, camedor palm, and banana $\left(18^{\circ} 43^{\prime} 03.34 " \mathrm{~N}\right.$, 96 50'55.88” W; $1054 \mathrm{~m}$ a.s.l.), we observed an adult Bromeliohyla dendroscarta [snout-vent length (SVL) $31.5 \mathrm{~mm}$ ] in a bract of bananas. The frog were captured by hand, photographed, and released; we deposited a photo voucher in the University of Texas at Arlington Digital Collection (UTADC-9265). The dorsal coloration of the frog is uniform yellow, without patterns (Figure $3 \mathrm{H}$ ). The anterior and posterior surfaces of the thighs are yellow and the discs of the fingers are darker. The flanks are yellow-cream, the throat and belly are white, and the iris is golden with shades of bronze and tenuous black reticulations. We resampled this site on 02 October 2017, but did not find any adult of $B$. dendroscarta.

Additionally, on 26 April 2016 at about 15:00 h, Cerón-de la Luz (pers. comm.) found an individual adult $B$. dendroscarta $(\mathrm{SVL}=30 \mathrm{~mm})$ in a bract of a Musa sp. in a patch of coffee at Acticpac (18³4'16.19" N, 9653'13.61" W; WGS 84; $597 \mathrm{~m}$ a.s.1.) in the municipality of Zongolica in the state of Veracruz. At this site, the predominant vegetation is semideciduous tropical forest along with patches of shadegrown coffee and banana.

On 03 October 2017 at ca. 12:50 h, we observed eight tadpoles and three anuran egg masses in bromeliad phytotelmata (Tillandsia sp.; Figure 2E-F) growing $0.3-3 \mathrm{~m}$ above the ground in a patch of semideciduous tropical forest (18 42'54.63" N, 96 50'57.90" W; WGS $84 ; 1141 \mathrm{~m}$ a.s.1.). Five and three tadpoles were in each of two bromeliads, respectively. The tadpole bodies are depressed dorsoventrally; the small eyes are lateral and body color ranges from white to translucent cream (Figure 3F). The egg masses were in two other bromeliads. One had two egg masses containing three living and four dead eggs, and the second bromeliad had a single egg mass with five eggs. The mass with four eggs was covered by water, which may have been the cause of the death of the embryos. The egg diameter ranged from $23-31 \mathrm{~mm}$; the eggs have a slightly milky, translucent coloration, and a uniformly cream vitellus (Figure $3 \mathrm{~A}$ ). We made our observations on the mass that contained three eggs.

On 06 October 2017, the embryos were in Gosner Stage 18; we observed spasmodic muscular responses (simple flexures) and division of the gill plate into ridges (visceral arches) (Figure 3B). On October 09 just prior to hatching, one embryo was in Stage 20. We based this on our observation that circulation in gills was absent and the cornea was opaque (Figure 3C); both of the latter are characteristic of Stage 21. On 10 October 2017, all tadpoles had hatched and had the same developmental characteristics (Figure 3D). The tadpoles had advanced to Stage 25 on 13 October, when the gills were atrophied and the spiracle had developed on the left side of the body (Figure 2E). We found a recent metamorph in Stage 45 on 06 February 2018 in one of the egg-bearing bromeliads. The lateral eyes of the froglet were well developed and the corner of the mouth was located posterior to the level of the eye, and vestiges of tail remained. The dorsum and extremities were yellowishgreen but the rest of body was translucent white; the iris was yellow (Figure 3G). We also observed tadpoles feeding on plant detritus and the body of an arthropod (order Orthoptera) in the bromeliad phytotelmata (Figure 4).

On 13 May 2018 in an ecotone of semideciduos tropical forest and montane cloud 


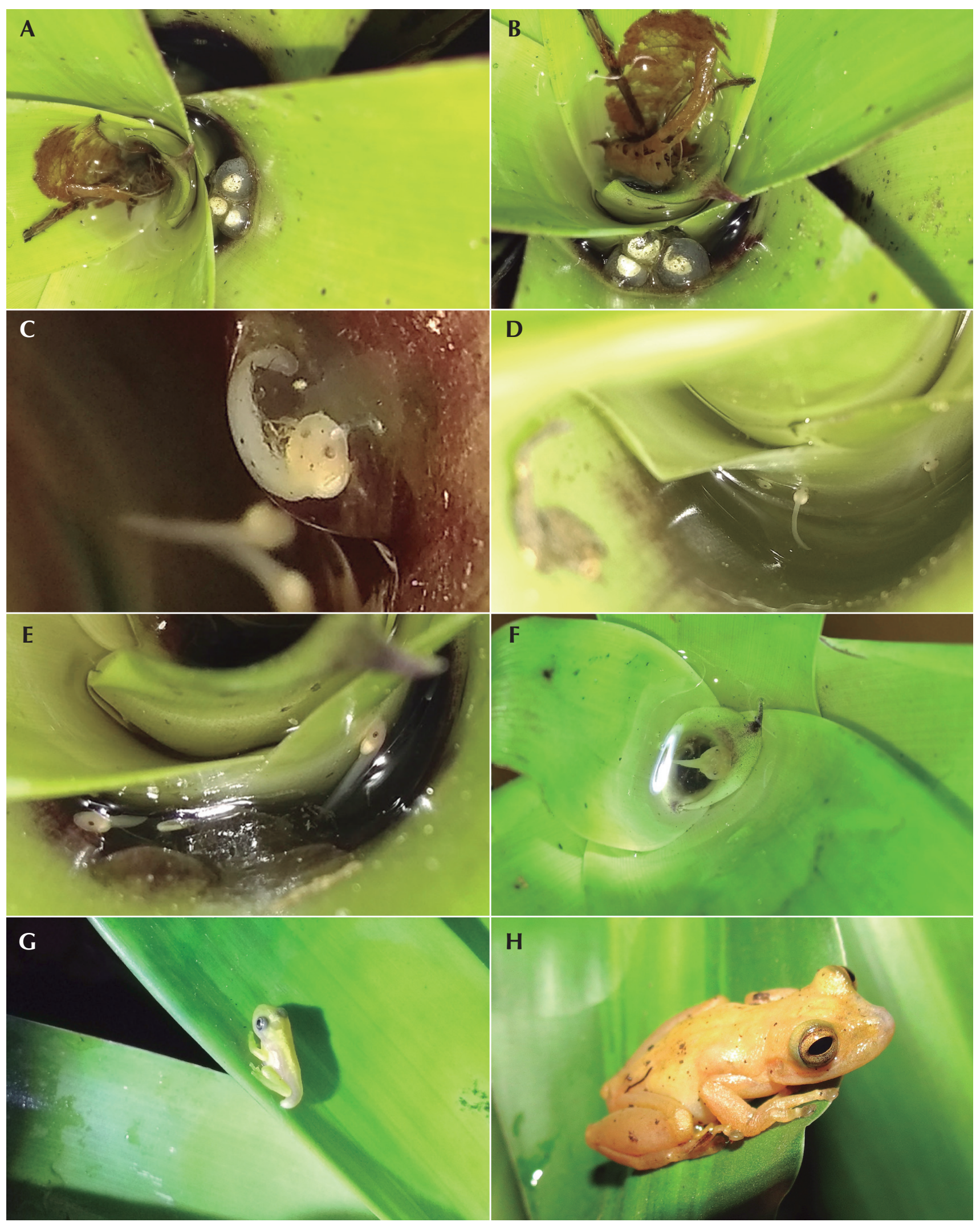

Figure 3. Morphology of embryonic development (A-C), larvae (D-F), postmetamorphic juvenile $(\mathbf{G})$ and adult $(\mathbf{H})$ of Bromeliohyla dendroscarta of the Colonia Agrícola Rincón de las Flores, Tezonapa, Veracruz. Photos by Arleth Reynoso-Martínez (A-D, F) and Víctor Vásquez-Cruz (E, G, H). 


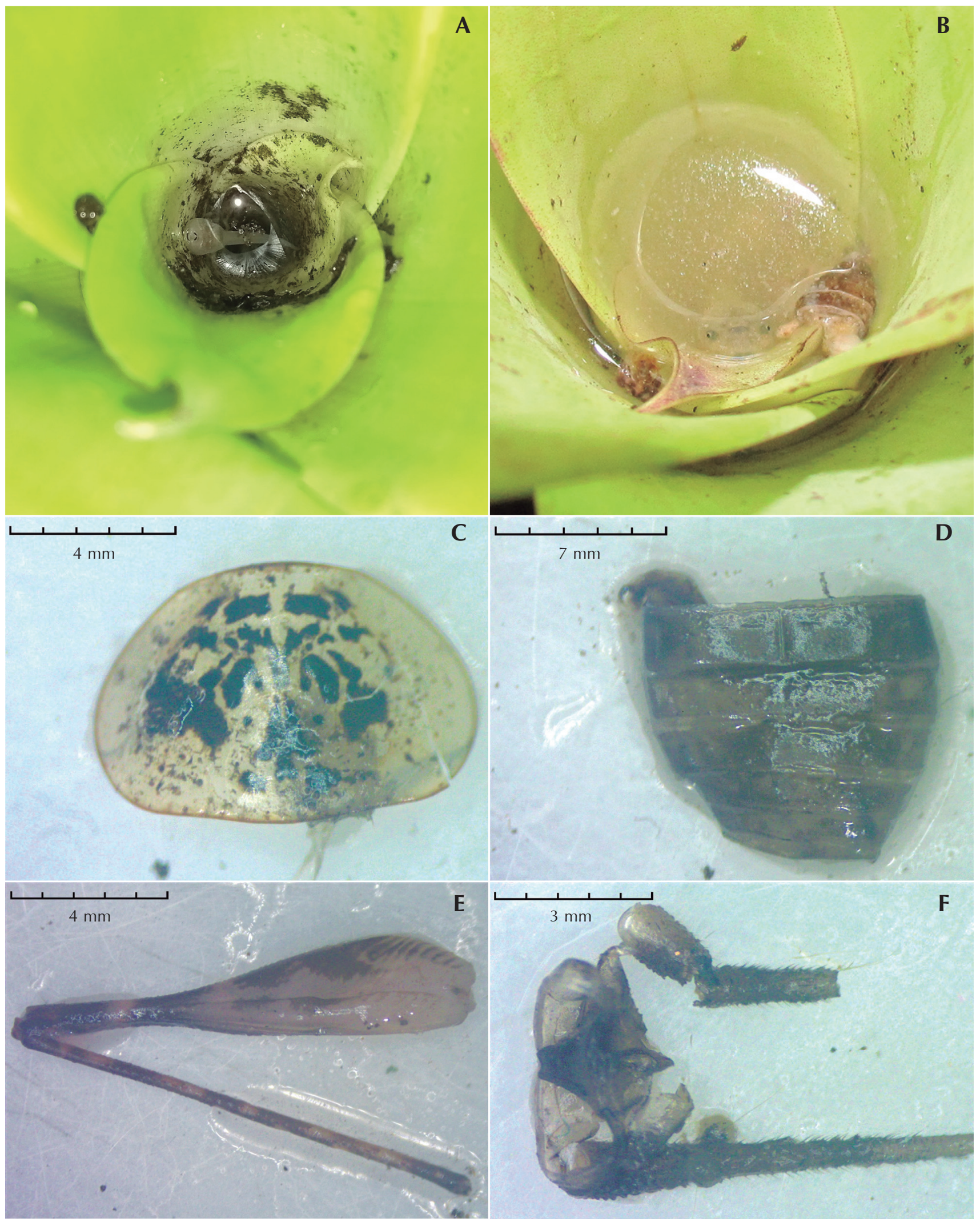

Figure 4. Tadpoles of Bromeliohyla dendroscarta feeding on detritus on the water surface (A) and on an arthropod (B). Remains of the arthropod determined as an individual of order Orthoptera (C-F). Photos by Arleth ReynosoMartínez (A) and Víctor Vásquez-Cruz (B-F). 
forest (1842'36.63" N, 9651'8.36" W; WGS 84; $1326 \mathrm{~m}$ a.s.1.), we observed a tadpole and two different egg clutches in the same bromeliad, which was located 2.6-3 m above the ground. One egg mass contained five eggs in Stage 14, and the other, eight eggs in Stage 19.

\section{Discussion}

The characteristics of the adult and tadpoles match those described for Bromeliohyla dendroscarta by Duellman (1964, 2001) and Canseco-Márquez et al. (2018), thereby confirming our identification of the species. Our two new records from localities Acticpac and Colonia Agrícola Rincón de las Flores complement the distribution of $B$. dendroscarta because they are 33.5 and $23.3 \mathrm{~km}$, respectively, southwest of the type locality (Figure 4). Previously, only montane cloud forest and pineoak forest were known to support $B$. dendroscarta, and both are considered threatened (Mora-Donjuán and Alanís-Rodríguez 2016, Ochoa-Ochoa et al. 2017). To the latter, we now add semideciduous tropical forest; an ecotone of semideciduous tropical and montane cloud forest; and a mosaic of shade-grown coffee with banana, camador palm, and bromeliad-laden native trees as three new habitats known for $B$. dendroscarta. Although several studies document amphibians and reptiles inhabiting of coffee agroecosystems in Mexico (e.g., Pineda et al. 2005, Macip-Ríos and Casas-Andreu 2008), none reported the presence of $B$. dendroscarta. Recently, García-Bañuelos et al. (2017) reported the presence of $B$. dendroscarta in a small parch of cloud forest surrounded by coffee.

Previously, numerous tadpoles and egg masses of B. dendroscarta had been reported in large bromeliads (60-130 cm diameter) in January, February, July, and August (Duellman 1964, 2001, García-Bañuelos et al. 2017, Canseco-Márquez et al. 2018). Our observations occurred in the months of October and May, and involved smaller bromeliads $(25-35 \mathrm{~cm}$ diameter) with fewer clutches and tadpoles. This supports the suggestion of García-Bañuelos et al. (2017) that this species reproduces throughout much of the year. Further, we hypothesize that previous records of numerous clutches and tadpoles reflect multiple oviposition events.

Although, other species that reproduce in bromeliads feed their tadpoles with eggs, as is the case of Triprion spinosus (Steindachner, 1864) and Aparasphenodon arapapa Pimenta, Napoli, and Haddad, 2009 (Jungfer 1996, Lourenço-deMoraes et al. 2013), we no found evidence of such behavior. The tadpoles did not contain eggs in their stomachs and adults were not observed near the bromeliads; thus, it seems likely that the tadpoles feed on what they find in the bromeliad.

Given the existence of these additional populations of $B$. dendroscarta, this endemic, highly imperiled species seems to have broader habitat tolerances than previously documented, and offers an opportunity for detailed study of its biology in the future. However, the near future of these populations is uncertain. Agricultural activity is increasing in the area, and even more worrisome is the presence of the chytrid fungus in nearby areas since the 1970s (Cheng et al. 2011).

\section{Acknowledgments}

We thank Adam G. Clause for valuable suggestions that improved the manuscript, and to María Fernanda Díaz Rodríguez, Axel FuentesMoreno, and Adriana Sandoval-Comte for help in the preparation of the manuscript. We are grateful to Diego Alberto Zepahua Xochiquistle, Nelson Martín Cerón de la Luz, and Eunice Ballona-Hernández for field assistance, and thank Raúl Andrés Díaz-Ramos and Alfonso Kelly-Hernández for field assistance and providing photographs Figure 1C, F and Figure 1E, respectively. Norma Mora-Gallardo for assistance to take photographs of the remains of the arthropod; and Carl J. Franklin (UTA) for cataloguing the digital photographs. Special thanks to two anonymous reviewers for their comments from which the manuscript greatly benefited. 


\section{References}

Aranda-Coello J. M., O. M. M. Velázquez, A. G. Cruz, J. C. Díaz, C. A. V. Escobar, N. M. Hérnandez, and E. A. M. Cabrera. 2018. Ausencia de anfibios en bromelias de tanque en la Estación Biológica San José, Chiapas, México. UNED Research Journal Costa Rica 10: 216218.

Barrios-Amorós, C. L., U. O. García-Vázquez, M. Domínguez-Laso, and A. Nieto-Montes de Oca. 2016. Charadrahyla altipotens (Anura: Hylidae), a Critically Endangered tree-frog rediscovered in Oaxaca, Mexico. Mesoamerican Herpetology 3: 787-790.

Canseco-Márquez L., J. L. Aguilar-López, R. LuríaManzano, G. Gutierrez-Mayén, and D. HernandezBenitez. 2018. Rediscovery of two threatened species of treefrogs (Anura: Hylidae) from southern Mexico. Herpetology Notes 11: 23-29.

Caviedes-Solis, I. W., L. F. Vázquez-Vega, I. SolanoZavaleta, E. Pérez-Ramos, S. M. Rovito, T. J. Devitt, P. Heimes, O. A. Flores-Villela, J. A. Campbell, and A. Nieto Montes de Oca. 2015. Everything is not lost: recent records, rediscoveries, and range extensions of Mexican hylid frogs. Mesoamerican Herpetology 2: 230-241.

Cheng, T. L., S. M. Rovito, D. B. Wake, and T. V. Vance. 2011. Coincident mass extirpation of Neotropical amphibians with emergence of the infectious fungal pathogen Batrachochytrium dendrobatidis. Proceedings of the National Academy of Sciences 108: 502-507.

Collins, J. P. and A. Storfer. 2003. Global amphibian declines: sorting the hypotheses. Diversity and Distributions 9: 89-98.

Delia, J. R. J., J. L. Whitney, and T. Burkhardt. 2013. Rediscovery of 'lost' treefrogs from the Oaxacan highlands of Mexico. Biodiversity and Conservation 22: $1405-1414$.

Duellman, W. E. 1964. Description of a new species of tree frog from Veracruz, Mexico. Herpetologica 19: 225228 .

Duellman, W. E. 2001. The Hylid Frogs of Middle America. 2 Volumes. $2^{\text {nd }}$ Edition. Ithaca. Contributions to Herpetology, Volume 18, Society for the Study of Amphibians and Reptiles. 1180 pp.

Frías-Alvarez, P., J. J. Zúñiga-Vega, and O. Flores-Villela. 2010. A general assessment of the conservation status and decline trends of Mexican amphibians. Biodiversity and Conservation 19: 3699-3742.
Frost, D. R. (ed.). 2018. Amphibian Species of the World: An Online Reference. Version 6.0 (26 April 2018). Electronic Database accessible at http://research.amnh. org/herpetology/amphibia/index.html. American Museum of Natural History, New York, USA. Captured on 26 April 2018.

García-Bañuelos, P., J. L. Aguilar-López, E. Pineda, and A. García-Vinalay. 2017. Rediscovery of Bromeliohyla dendroscarta at the type locality: a threatened treefrog surviving in a highly human modified landscape in Mexico. Mesoamerican Herpetology 4: 684-688.

Gómez, M. L., V. H. Zaracho, and M. T. Sandoval. 2016. Desarrollo embrionario-larval y metamorfosis de Physalaemus albonotatus (Anura: Leptodactylidae). Revista Veterinaria 27: 21-27.

Gosner, K. L. 1960. A simplified table for staging anuran embryos and larvae with notes on identification. Herpetologica 16: 183-190.

Grünwald, C. I., H. Franz-Chávez, and U. O. GarcíaVázquez. 2016. Rediscovery of the Critically Endangered treefrog Charadrahyla trux in the Sierra Madre del Sur of Guerrero, Mexico. Mesoamerican Herpetology 3: 790-793.

Hernández-Salinas, U. and A. Ramírez-Bautista. 2012. Diversity of amphibian communities in four vegetation types of Hidalgo state, Mexico. Open Conservation Biology Journal 6: 1-11.

Jungfer, K. H. 1996. Reproduction and parental care of the coronated treefrog, Anotheca spinosa (Steindachner, 1864) (Anura: Hylidae). Herpetological 52: 25-32.

Kays, R. and A. Allison. 2001. Arboreal tropical forest vertebrates: current knowledge and research trends. Plant Ecology 153: 109-120.

Lamoreux, J. F., M. W. McKnight, and R. CabreraHernández. 2015. Amphibian alliance for zero extinction sites in Chiapas and Oaxaca. Occasional Paper of the IUCN Species Survival Commission 53: 1-320.

Lourenço-de-Moraes, R., A. S. F. Lantyer-Silva, L. F. Toledo, and M. Sole. 2013. Tadpole, oophagy, advertisement call, and geographic distribution of Aparasphenodon arapapa Pimenta, Napoli and Haddad 2009 (Anura, Hylidae). Journal of Herpetology 47: $575-579$.

Lemos-Espinal, J. and G. R. Smith. 2016. Amphibians and reptiles of the state of Hidalgo, Mexico. Check List 11: $1-11$. 
Lips, K. R., J. Diffendorfer, J. R. Mendelson III, and M. W. Sears. 2008. Riding the wave: reconciling the roles of disease and climate change in amphibian declines. PloS Biology 6: 441-454.

Macip-Ríos, R. and G. Casas-Andreu. 2008. Los cafetales en México y su importancia para la conservación de los anfibios y reptiles. Acta Zoológica Mexicana 24: 143159.

Mora-Donjuán, C. A. and E. Alanís-Rodríguez. 2016. Resiliencia de bosques de pino-encino en América: una visión global del estado actual. Revista Forestal Mesoamericana Kurú 13: 1-2.

Ochoa-Ochoa L. M., N. R. Mejía-Domínguez, and J. Bezaury-Creel. 2017. Priorización para la conservación de los Bosques de Niebla en México. Ecosistemas 26: $27-37$.

Parra-Olea, G., O. A. Flores-Villela, and C. MendozaAlmeralla. 2014. Biodiversidad de anfibios en México. Revista Mexicana de Biodiversidad. Suplemento 85: 460-466.

Pineda, E., C. Moreno, F. Escobar, and G. Halffter. 2005. Frog, bat, and dung beetle diversity in the cloud forest and coffee agroecosystems of Veracruz, Mexico. Conservation Biology 19: 400-410.
Rovito S. M., G. Parra-Olea, C. R. Vásquez-Almazán, T. J. Papenfuss, and D. B. Wake. 2009. Dramatic declines in neotropical salamander populations are an important part of the global amphibian crisis. Proceedings of the National Academy of Sciences 106: 3231-3236.

Santos-Barrera, G. and L. Canseco-Márquez. 2004. Bromeliohyla dendroscarta. The IUCN Red List of Threatened Species 2004: e.T55466A11315413. Electronic Database accessible at http://dx.doi. org/10.2305/IUCN.UK.2004.RLTS.T55466A11315413. en. Captured on 17 April 2018.

SEMARNAT (Secretaría de Medio Ambiente y Recursos Naturales). 2010. Norma Oficial Mexicana NOM-059SEMARNAT-2010. Protección ambiental de especies nativas de México de flora y fauna silvestres. Categorías de riesgo y especificaciones para su inclusión, exclusión o cambio. Lista de especies en riesgo. Diario Oficial de la Federación, Segunda Sección, 30 de Diciembre de 2010, Ciudad de México, México: 1-77.

Stuart, S. N., J. S. Chanson, N. A. Cox, and B. E. Young. 2006. El estado global de los anfibios. Pp. 19-42 in A. Angulo, J. V. Rueda-Almonacid, J. V. RodríguezMahecha, and E. La Marca (eds.), Técnicas de Inventario y Monitoreo para los Anfibios de la Región Tropical Andina. Bogotá. Conservación Internacional, Andes CBC.

Editor: Carlos Arturo Navas 